\title{
Small Kingdoms and Crumbling Organizations: \\ Examining the Variation in Constituency Party Membership and Resources
}

\author{
Justin Fisher (Brunel University)
}

The 'revisionist school' of party campaigning in Britain has successfully demonstrated the importance of party members (see, for example, Denver and Hands, 1997; Johnston and Pattie, 1995; and Seyd and Whiteley, 1992). We have, however, much less information about the size and resources of local constituency parties. This article reports data collected during the Committee on Standards in Public Life's investigations into party finance. The aim of the survey was to gain an impression of the resources and expenditure of local parties in a manner similar to the investigations undertaken during the Houghton Committee's investigations in the 1970s. The article then analyses predictors of local party strength.

\section{Data}

The Committee's principal interests dictated the data collection. The sample was a random stratified sample of 60 cases drawn from the 529 English constituencies. Constituencies were stratified by the following four characteristics: marginality of seat; region; type of seat; and winning party at the 1992 general election. All cases were grouped according to these four characteristics, and 60 cases were then drawn using a systematic sample from a random start point.

Questionnaires were sent to constituency party secretaries. The valid response rate was exactly 50 per cent, though the response rate from Conservative constituency parties was far higher than for both Labour and the Liberal Democrats. It was apparent from the responses that the post of constituency secretary is one held with 
widely varying degrees of willing. This is one of the explanations for the variable standard of questionnaire completion. Indeed, some parties wrote to claim that somewhat straightforward information was simply untraceable. Despite this, as Table 1 illustrates, the responses match the population and sample profiles well. 
TABLE 1

COMPARISON OF POPULATION, SAMPLE AND RESPONSE CHARACTERISTICS

\begin{tabular}{|c|c|c|c|c|c|c|c|c|c|c|}
\hline & \multicolumn{2}{|c|}{ Population } & \multicolumn{2}{|c|}{ Sample } & \multicolumn{2}{|c|}{ Con } & \multicolumn{2}{|c|}{ Lab } & \multicolumn{2}{|c|}{ Lib Dem } \\
\hline & $\mathrm{n}$ & $\%$ & $\mathrm{n}$ & $\%$ & $\mathrm{n}$ & $\%$ & $\mathrm{n}$ & $\%$ & $\mathrm{n}$ & $\%$ \\
\hline Marginal Seats & 134 & 25 & 15 & 25 & 11 & 24 & 5 & 21 & 6 & 29 \\
\hline Non-Marginal Seats & 395 & 75 & 45 & 75 & 34 & 76 & 19 & 79 & 15 & 71 \\
\hline South East & 191 & 36 & 21 & 35 & 16 & 36 & 9 & 38 & 6 & 29 \\
\hline Midlands & 125 & 24 & 14 & 23 & 11 & 24 & 5 & 21 & 8 & 38 \\
\hline North & 162 & 31 & 20 & 33 & 14 & 31 & 8 & 33 & 6 & 29 \\
\hline South West & 51 & 10 & 5 & 8 & 4 & 9 & 2 & 8 & 1 & 5 \\
\hline Borough & 261 & 49 & 29 & 48 & 20 & 44 & 8 & 33 & 9 & 43 \\
\hline County & 268 & 51 & 31 & 52 & 25 & 56 & 16 & 67 & 12 & 57 \\
\hline Con Seat & 324 & 62 & 35 & 58 & 28 & 62 & 17 & 71 & 15 & 71 \\
\hline Lab Seat & 196 & 37 & 23 & 38 & 15 & 33 & 6 & 25 & 5 & 24 \\
\hline Lib Dem Seat & 9 & 2 & 2 & 3 & 2 & 4 & 1 & 4 & 1 & 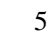 \\
\hline Total Cases & 529 & 100 & 60 & 100 & 45 & 100 & 24 & 100 & 21 & 100 \\
\hline
\end{tabular}




\section{Membership Levels}

Table 2 gives the figures for the size of constituency parties between 1992 and 1997.

The picture is a very mixed one. 
TABLE 2

\section{PARTY MEMBERSHIP}

n Mean StdDev Min Max

\section{Conservatives}

$\begin{array}{rrrrrr}1992 & 32 & 1,045 & 946.2 & 8 & 3,953 \\ 1993 & 33 & 967 & 853.4 & 6 & 3,345 \\ 1994 & 34 & 878 & 794.4 & 6 & 3,022 \\ 1995 & 38 & 826 & 755.5 & 11 & 2,611 \\ 1996 & 39 & 843 & 688.3 & 18 & 2,500 \\ 1997 & 43 & 809 & 711.1 & 15 & 2,838\end{array}$

Labour

$\begin{array}{rrrrrr}1992 & 9 & 409 & 248.0 & 168 & 925 \\ 1993 & 10 & 410 & 238.6 & 147 & 889 \\ 1994 & 16 & 405 & 232.4 & 161 & 1,040 \\ 1995 & 17 & 518 & 283.5 & 235 & 1,233 \\ 1996 & 20 & 561 & 252.5 & 270 & 1,242 \\ 1997 & 23 & 578 & 241.7 & 273 & 1,218\end{array}$

Liberal Democrats

$\begin{array}{llllll}1992 & 17 & 231 & 193.6 & 30 & 770 \\ 1993 & 17 & 226 & 207.0 & 50 & 817 \\ 1994 & 15 & 241 & 206.6 & 41 & 772 \\ 1995 & 19 & 230 & 193.6 & 35 & 740 \\ 1996 & 20 & 217 & 183.6 & 30 & 707 \\ 1997 & 20 & 211 & 173.2 & 28 & 652\end{array}$


For the Conservatives, there is a clear pattern of decline. In 1992, the mean number of constituency party members was 1,045. By 1997 it was 809. Local Liberal Democrat membership also appears to have declined, though not to the same extent as the Conservatives. Mean membership in 1992 was 231, whilst in 1997 it was 211. However, Labour's local membership increased during this period. In 1992, the mean membership was 409, whilst in 1997 it was 578. Moreover, the data also suggest that the increase in membership was particularly apparent after 1994. This pattern reflects the national picture whereby that the leadership of Blair (at least until 1997) had a positive impact upon the size of the membership (Seyd: 1998: 68).

However, despite this decline, the Conservatives still have the larger constituency parties. The largest Conservative constituency party in $1997(2,838)$ was more than double the largest Labour constituency party, and was four times the size of the largest Liberal Democrat party. And the average (mean) figure was 809, noticeably larger than the mean for Labour (578) and almost four times that of the Liberal Democrats (211).

Yet these mean figures hide a considerable range. In 1993 and 1994, one Conservative constituency party had only six members, whilst in 1992, one had almost 4,000. The range of party sizes was far less pronounced for Labour - the lowest constituency party size recorded being 147 , the highest 1,242 - but was still dramatic. The Liberal Democrats had the lowest dispersion of party sizes - the smallest party having 28 members, the largest 817 - but even here the largest party was almost 30 times the size of the smallest. 
These figures compare well with the findings of Denver and Hands in $1997 .{ }^{1}$ Using estimates of party membership by election agents rather than constituency secretaries, the comparable means for parties in English constituencies was 781, 616 and 173 for the Conservatives, Labour and Liberal Democrats respectively. In addition, the broad trends in membership are also borne out by studies from 1992 and 1997, although the decline in Conservative members (at least in English seats) does not appear to be as marked as that observed by Denver and Hands (1998: 78-9).

The implications of these data are important. Firstly, questions of political legitimacy must arise where a party has as few as six members in an entire constituency. That party may stand no chance of winning the seat in question, but it would seem a matter of concern for a party to field a candidate in an area where it had such tiny support. Quite apart from the question of mounting a campaign with so few members, the small size inevitably means that the roles of members identified by Seyd and Whiteley and others can scarcely be fulfilled. On the other hand, of course, some local parties are very strong in membership terms. Nevertheless, the wide dispersion is likely to be of concern to parties.

\section{Income}

Party income is also a key variable in terms of organizational strength. Whilst volunteer members can fulfil many functions unpaid, parties require money to field candidates, campaign in and between elections and simply to maintain a presence in the community. Local parties do not exist only at the times of elections, though they may be more visible at those times. Rather, parties attempt to maintain contact with the electorate throughout the various electoral cycles. Moreover, significant party activity takes place before the formal campaign begins in order to maximize the 
efficiency of the campaign effort (Denver and Hands, 1998: 80-1). In effect, many parties are almost continually campaigning due to the staggered local elections throughout the general election cycle. And for this, they need money.

Table 3 shows the income of local constituency parties between 1992 and 1997, standardized at 1992 prices. As with the figures for membership, it reveals very wide variations, both between and within the parties. 
TABLE 3

TOTAL PARTY INCOME

$\begin{array}{lcccrc} & \mathrm{n} & \begin{array}{c}\text { Mean } \\ £ s\end{array} & \text { StdDev } & \begin{array}{r}\text { Min } \\ £ s\end{array} & \begin{array}{r}\text { Max } \\ £ s\end{array} \\ \text { Conservatives } & & & & & \\ 1992 & 40 & 47,245 & 44462.6 & 550 & 228,521 \\ 1993 & 41 & 36,315 & 37686.8 & 128 & 209,784 \\ 1994 & 41 & 34,626 & 40527.1 & 206 & 219,631 \\ 1995 & 44 & 32,028 & 40478.2 & 120 & 224,485 \\ 1996 & 45 & 33,587 & 43967.3 & 779 & 240,055 \\ 1997 & 45 & 33,713 & 38694.0 & 738 & 187,075\end{array}$

Labour

$\begin{array}{rrrrrr}1992 & 13 & 7,289 & 6576.9 & 1,339 & 24,960 \\ 1993 & 13 & 5,614 & 5694.2 & 829 & 22,913 \\ 1994 & 16 & 4,473 & 4630.7 & 125 & 18,854 \\ 1995 & 23 & 6,299 & 10168.2 & 608 & 46,485 \\ 1996 & 24 & 7,826 & 9898.2 & 885 & 41,757 \\ 1997 & 24 & 8,226 & 13309.3 & 744 & 58,800\end{array}$

Liberal Democrats

$\begin{array}{llllll}1992 & 17 & 4,911 & 5302.8 & 398 & 17,112 \\ 1993 & 17 & 2,975 & 4126.1 & 176 & 15,992 \\ 1994 & 18 & 3,003 & 4013.8 & 171 & 15,036 \\ 1995 & 20 & 3,048 & 4435.6 & 102 & 16,985 \\ 1996 & 21 & 3,830 & 5989.8 & 239 & 18,319 \\ 1997 & 21 & 6,056 & 8760.4 & 385 & 24,164\end{array}$

Note: All income standardized at 1992 Prices. 
The Conservative Party is the wealthiest party at local level by some margin. The average income of a Conservative constituency party in 1997 was more than double the average of both Labour and the Liberal Democrats combined. However, local Conservative Parties are suffering a decline in income. Mean Conservative income fell from around $£ 47,000$ in 1992 to just under $£ 34,000$ in 1997 . Labour’s mean income in 1992 was just over $£ 7,000$, and whilst there was a mid-general election cycle dip, the 1997 mean had risen to just over $£ 8,000$. The Liberal Democrats experienced a similar cycle, with a mean income in 1992 of almost $£ 5,000$, reaching just over $£ 6,000$ in 1997 .

Yet the range of parties' incomes is very broad. The dispersion of Conservative local parties' income is considerably wider than is the case for Labour or the Liberal Democrats. It is clear that whilst there are some small kingdoms in evidence, there are also some paupers as well. Again therefore, there must some question as to how well constituency parties can operate with such low incomes. Moreover, it would seem that the Conservative Party as a whole would benefit from a degree of crosssubsidy.

For all parties, and for each year, levels of individual membership are positively correlated with levels of income. (The lowest correlation coefficient in any one year was 0.52 , whilst the highest was 0.89 ; all coefficients were statistically significant at the 0.05 level, with all but one significant at the 0.01 level). This may interpreted in two ways. It could be that an increase in membership leads to an increase in income. Alternatively, however, it could be that the more wealthy and established constituency parties are more able to recruit members, since they will be likely to be more visible and may offer more opportunities for recruitment. 
Moreover whilst all parties appear to benefit financially from larger memberships, the relationship varies between parties. There is a stronger relationship for the Liberal Democrats than is the case for the other parties. For example, taking the mid-cycle year of 1995, the correlations were $0.59,0.67$ and 0.89 for the Conservatives, Labour and Liberal Democrats respectively. ${ }^{2}$

\section{Expenditure}

Questions about the importance of expenditure reflect those of income, namely the functionality and legitimacy of parties that are unable to fund their activities. Of course, a wealthy party spending no money would fulfil few of its functions, but a party without any money is not able to spend it. Table 4 provides figures for the expenditure of the parties between 1992 and 1997, again with all prices standardized at 1992 levels. 
TABLE 4

TOTAL PARTY EXPENDITURE

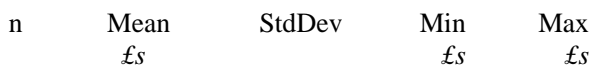

Conservative

$\begin{array}{rrrrrr}1992 & 39 & 43,703 & 31967.2 & 1,050 & 105,427 \\ 1993 & 40 & 34,737 & 27444.6 & 0 & 96,882 \\ 1994 & 40 & 33,714 & 29089.8 & 144 & 101,487 \\ 1995 & 43 & 29,636 & 29003.8 & 120 & 118,995 \\ 1996 & 45 & 31,272 & 34496.4 & 495 & 161,531 \\ 1997 & 45 & 31,306 & 30025.8 & 1,295 & 109,886\end{array}$

Labour

$\begin{array}{llrrrr}1992 & 13 & 9,269 & 9250.3 & 1,949 & 28,226 \\ 1993 & 14 & 5,855 & 6911.5 & 602 & 27,476 \\ 1994 & 15 & 4,490 & 4214.8 & 0 & 14,532 \\ 1995 & 23 & 5,715 & 8534.1 & 573 & 37,674 \\ 1996 & 24 & 7,475 & 10350.4 & 821 & 45,038 \\ 1997 & 23 & 9,022 & 14146.9 & 471 & 60,570\end{array}$

Liberal Democrats

$\begin{array}{llllrl}1992 & 16 & 5,454 & 5124.3 & 163 & 15,162 \\ 1993 & 15 & 2,768 & 3828.7 & 68 & 14,308 \\ 1994 & 16 & 3,206 & 4286.4 & 122 & 14,806 \\ 1995 & 17 & 3,613 & 4471.6 & 188 & 15,433 \\ 1996 & 19 & 3,608 & 5921.9 & 13 & 18,409 \\ 1997 & 20 & 7,016 & 9205.8 & 459 & 24,164\end{array}$

Note: All expenditure standardized at 1992 Prices. 
The spending of Conservative local parties declined slightly after 1993, with a dramatic lowering of spending in the election year of 1997 relative to 1992. The mean expenditure in 1992 was almost $£ 44,000$, but by 1997 it had fallen to just over $£ 31,000$. The mean level of Labour spending also fell, but only very slightly (from $£ 9,269$ in 1992 to $£ 9,022$ in 1997). In contrast, the level of Liberal Democrat spending increased during this period, rising from around $£ 5,500$ in 1992 to over $£ 7,000$ five years later.

For all parties, the range of expenditure varied considerably. One local Conservative party reported spending nothing in 1993; another spent only $£ 120$ in 1995 . Yet one local Conservative party spent over $£ 161,000$ in 1996 . There was also a wide range of expenditures for local Labour parties. One reported spending no money in one year, while another spent only $£ 471$ in 1997 . The same year saw another spend over $£ 60,000$. For the Liberal Democrats, the range was between $£ 13$ spent by one party in 1996 to $£ 24,164$ spent by another in 1997.

For both Labour and the Liberal Democrats spending levels and dispersion reflected the general election cycle, suggesting that expenditure was far more differentiated at general elections. However, the general election cycle was not reflected in levels of Conservative spending (though this may be linked to falling membership and income over the period). Nor, however, was there any real pattern in the dispersion of expenditure. This suggests that the overall, relative levels of Conservative parties' expenditure changed little over the course of the cycle, which in turn suggests that party expenditures at general elections were less targeted than one might expect. 
Overall, whilst Conservative spending fell, their constituency parties still spent considerably more than the other parties year on year. Clearly, this is a function of those parties generating more income, but the result is a clear disparity between the local parties' ability to spend money year on year. This is significant, because whilst party spending is restricted during election campaigns, there is no restriction between campaigns. Parties do not enter campaigns from a base starting point; thus a party's presence in the community will be cumulative. It might logically be argued therefore that expenditure levels both at and between elections would contribute to that presence (although at a national level, levels of year-on-year party spending have only a negligible effect upon levels of party popularity: see Fisher, 1999). If that is the case, the Conservatives have a clear and substantial advantage over the other parties. In turn Labour has an advantage over the Liberal Democrats, though that advantage is neither as pronounced as that between Conservatives and Labour at this level, nor between Labour and the Liberal Democrats at national level.

\section{Influences on Party Strength}

This section of the article examines aggregate predictors of local party strength, with strength being defined in terms of membership, income and expenditure. Analyses using the Committee on Standards in Public Life (CSPL) data set are necessarily limited. The small sample size means that only bivariate analyses can reasonably be conducted and even then, the results should only be seen as broadly indicative. Nevertheless, the analyses do appear to display clear patterns that are worthy of note. However, the larger data set collected by Denver and Hands, which contains estimated levels of local party membership, allows us to analyse this variable more extensively. 
Three sets of independent variables were selected, covering social, political and structural variables. The social variables selected were those commonly used to predict turnout (see for example Denver, 1998) as well as variables identified as being important by the party membership surveys (Seyd and Whiteley, 1992; Whiteley et al., 1994). These cover class composition, population density, car ownership, housing tenure, age and ethnicity, and are all derived from the 1991 census.

The political variables concerned the electoral status of the constituencies. Three different variables were employed. First, marginality was used for parties placed either first or second in that constituency at the previous election. This variable has been used successfully by Denver and Hands $(1997,1998)$ to predict strength of party election campaigns.

However, in assessing party strength (as opposed to an election campaign), there is reason to suggest that this variable may not be wholly appropriate. The size of a party election campaign can change relatively easily depending upon the result of the previous election. If a seat becomes safe, it is relatively easy to downsize the subsequent campaign. With party organization, however, institutional inertia may mean that any change is more gradual and less responsive to individual election results. What is required, therefore are variables that measure a longer-term view of the likelihood of winning the seat. Two variables were used to capture this effect: an 'Index of Hope', based upon position in elections from 1979 onwards, and a measure of the net change in marginality in the seat for parties placed first or second, again in the period since 1979 . 
The Index of Hope was calculated by giving scores to the first or second placed party in each constituency. That score diminished the further the election was from time $t$. This captures whether a party at least had a chance of winning a seat over a period of up to four general elections. Thus, if a party had been in contention for a seat between 1979 and 1987, but not in 1992, the likelihood would be that the party organization would decline less rapidly than the electoral support. Details regarding the scoring on the index are provided in the Appendix.

The Index of Hope however, only captures party position, not the scale of victory or defeat. An additional variable was therefore calculated which captured the net change in the winning party's margin of victory since 1979. If the winning margin were declining, this would stimulate membership and expenditure for both incumbent and opposition. Conversely, if the margin was widening, the reverse might occur, at least for the opposition. Again, details of this variable's construction are provided in the Appendix.

Unfortunately, for both of these variables there have been two boundary reviews since 1979, thus preventing exact comparison between different elections. This problem was addressed in the following way. The constituencies used for comparison in 1992, 1987 and 1983 were those that have been the largest single constituency represented in the new (1997) constituency. The same process was employed for constituencies in 1979. This is not a wholly exact measure, but it does capture the fact that whilst boundaries may change, local organization may change less rapidly, and thus the political history of the area will continue to have some impact, even if the actual constituency boundary has changed. 
The final set of variables was structural, and was designed to test the impact of boundary reorganization upon local parties. Two variables were used: the Boundary Change Index which represents the extent of change involved in the creation of the new constituency (Rallings and Thrasher, 1995); and an index of the number of local authorities represented within the constituency. A higher Boundary Change Index together with a higher number of local authorities represented in a constituency should lead to greater disruption to the local party. This, in turn, should be reflected in its organizational strength.

\section{Membership}

Table 5 utilizes data collected by David Denver and Gordon Hands in their study of local party campaigning at the 1997 general election. Whilst these data are restricted to estimates of party membership in 1997, they offer two advantages over the CSPL data. First, the data cover Scotland and Wales in addition to England. Second, and more important, there are considerably more cases, permitting more detailed analysis of the data. That said, the following examinations were also run using the CSPL data. The results, although not reported here, bear out those found using the more extensive data set. 
TABLE 5

AGGREGATE CORRELATIONS WITH PARTY MEMBERSHIP 1997

\begin{tabular}{|c|c|c|c|c|c|c|}
\hline & \multicolumn{2}{|c|}{ Conservative } & \multicolumn{2}{|c|}{ Labour } & \multicolumn{2}{|c|}{$\begin{array}{c}\text { Liberal } \\
\text { Democrats }\end{array}$} \\
\hline & $r$ & $p$ & $r$ & $p$ & $r$ & $p$ \\
\hline \multicolumn{7}{|l|}{ Political } \\
\hline Index of Hope & .547 & $* *$ & .302 & $* *$ & .720 & $* *$ \\
\hline Marginality 1992 & .162 & $* *$ & -.154 & $* *$ & -.491 & $* *$ \\
\hline Change in Marginality $1979-1992$ & -.153 & $* *$ & .070 & & -.049 & \\
\hline \multicolumn{7}{|l|}{ Structural } \\
\hline Boundary Change Index & .003 & & -.119 & $* *$ & -.019 & \\
\hline Number of Local Authorities & .187 & $* *$ & -.196 & $* *$ & .144 & $* *$ \\
\hline \multicolumn{7}{|l|}{ Social } \\
\hline$\%$ Under $25 \mathrm{~s}$ & -.352 & $* *$ & .322 & $* *$ & -.315 & $* *$ \\
\hline$\%$ Households with car & .515 & $* *$ & -.442 & $* *$ & .427 & $* *$ \\
\hline$\%$ Council Renters & -.470 & $* *$ & .135 & $* *$ & -.437 & $* *$ \\
\hline$\%$ Owner Occupiers & .361 & $* *$ & -.268 & $* *$ & .301 & $* *$ \\
\hline$\%$ Private Renters & .154 & $* *$ & .219 & $* *$ & .232 & $* *$ \\
\hline$\%$ Economically Active & .324 & $* *$ & -.144 & $* *$ & .259 & $* *$ \\
\hline$\%$ Manual & -.478 & $* *$ & -.092 & & -.459 & $* *$ \\
\hline$\%$ Non-Manual & .489 & $* *$ & .062 & & .461 & $* *$ \\
\hline$\%$ Professional \& Managerial & .556 & $* *$ & .063 & & .519 & $* *$ \\
\hline$\%$ in Agriculture & .349 & $* *$ & -.326 & $* *$ & .288 & $* *$ \\
\hline Persons per hectare & -.256 & $* *$ & .458 & $* *$ & -.185 & $* *$ \\
\hline$\%$ White & .150 & $* *$ & -.478 & $* *$ & .155 & $* *$ \\
\hline$\%$ Non White & -.174 & $* *$ & .485 & $* *$ & -.179 & $* *$ \\
\hline $\mathrm{n}$ & 406 & & 443 & & 397 & \\
\hline
\end{tabular}


As Table 5 shows, at the bivariate level, political variables are linked to levels of local membership for all parties. In the case of the Conservative Party, the Index of Hope is positively correlated and as one might expect, the change in marginality between 1979 and 1992, is negatively correlated, which suggests that increasing competition over the period helped contribute to a growth in membership. On the other hand, marginality in the 1992 election is positively signed. This suggests that greater marginality in the short-term is not associated with higher membership. Rather, Conservative parties are more populous where their current electoral position is stronger. For both Labour and the Liberal Democrats, the Index of Hope is also positively associated, as is greater marginality at the 1992 election. The latter indicates that in the short term at least, the current (in 1997) political circumstances of a constituency provided an incentive for higher Labour and Liberal Democrat memberships.

Structural variables also have an impact for all parties. The number of local authorities represented in a constituency is positively related to both Conservative and Liberal Democrat local party memberships. This runs counter to the hypothesis that the greater diversity of political boundaries within a constituency would be detrimental to membership levels. For Labour, however, the relationship is as hypothesized: the disruption of boundary changes and the higher representation of local authorities in parliamentary constituencies has a negative impact on Labour memberships.

In terms of social variables, all those tested appear to have an association with Conservative membership consistent with what one might hypothesize. The proportion of young people is negatively associated. Car ownership is positively 
associated. Private tenure is positively associated, whilst public tenure is negatively so. Conservative parties flourish in areas of higher middle class composition. Agricultural employment and population density are associated consistently, so that Conservative memberships are higher is more rural and less densely populated areas. Finally, the proportion of non-whites is negatively associated with membership and vice versa.

The social profile of Liberal Democrat seats is similar to that of the Conservatives. Thus, membership is positively associated with higher car ownership, private housing tenure, higher social class composition and higher proportions of people employed in agriculture; and it is negatively associated with young people, public housing, higher proportions of manual workers and non-whites and higher population density.

However, the effect of social variables is not entirely as might be expected for local Labour parties. To be sure, larger proportions of the young and non-whites, higher population density, together with lower proportions of households with cars and persons employed in agriculture, all appear to be associated with higher levels of Labour membership. However, it is also worth noting that unlike the Conservatives, it is not the public/private housing dichotomy that is associated with membership. Rather it is ownership/non-ownership. In addition, at bivariate level, class as defined by occupation does not appear to impact upon membership. Only the proportion of economically active constituents (which would amongst other things, capture unemployment) is, as might be expected, negatively associated.

Income 
Given that party income is strongly related to the level of party members, it might be expected that aggregate associates of membership would also be those associated with income. Using the CSPL data, this is broadly the case. ${ }^{3}$ As far as political variables are concerned both Conservative and Liberal Democrat parties generate more income in areas of greater political strength. Moreover, for the Liberal Democrats, higher levels of marginality relative to the previous election are also strongly correlated with income, suggesting that local parties receive more money in marginal seats. For Labour, however, the association is counter-intuitive. The change over time in the size of the majority in the seat is significant, but positively correlated.

Structural variables are only associated with party income in the case of Conservative parties. The number of local authorities with wards in the constituency is positively associated with income. This finding is not as expected. It was hypothesized that this would be an indicator of organizational disruption, which might be expected to have a detrimental effect upon party resources. However, it appears as though the reverse may be the case, although this does fit with the aggregate correlations generated from the Denver and Hands data.

In terms of social variables, local Conservative parties generate most income in areas that one might expect; namely those with higher levels of economic activity, higher occupational class composition, higher proportions of owner occupancy, higher levels of car ownership and lower population density. Conversely, income is negatively correlated with higher proportions of manual workers and council tenants.

Similarly, in the case of Labour, those variables correlated with party income are also generally associated with party membership. Thus, the higher the density of 
population, proportion of younger people, private renters and non-whites, and the lower the level of car ownership and owner occupation, the higher the Labour party income. For the Liberal Democrats however, social variables have virtually no impact upon income.

\section{Expenditure}

Since expenditure relies upon income to an extent, there is again likely to be a similar range of variables associated with local party expenditure as there is with income. And indeed, that is broadly the case. ${ }^{4}$ Conservative parties spend more in wealthier and less populated areas, whilst Labour does the reverse. However, what are critical here are the 'political' variables, since we might expect spending to be strongly associated with the electoral status of the seat. In the case of the Conservatives, it appears that they spend most in the areas of greatest electoral strength, a pattern also discovered by Denver and Hands when examining local campaigns (1997: 256-7). This is also broadly true for Labour and the Liberal Democrats, however. That said, Liberal Democrat parties are unlike other parties in that they also spend more in marginal seats. 
Notwithstanding the small sample used in most of the analyses, these aggregate correlations suggest certain key patterns. First, political variables are useful for analysing patterns in local parties, especially in the case of the Liberal Democrats. Moreover, the impact of political variables is both long- and short-term. Party strength is generally affected by both long-term status as incumbent or principal opponent, and by recent marginality.

By contrast structural variables have a far less consistent impact. Moreover, what impact they have is unclear: at bivariate level at least, the impact of structural disruption is positive as well as negative, depending on the party. Finally, social variables are useful in analysing patterns of local strength for the Conservative and Labour parties, but much less so in the case of the Liberal Democrats.

\section{Multivariate Analysis of Membership}

These bivariate analyses only provide a partial and indicative picture. The larger number of cases in the Denver and Hands data allows for multivariate analysis, which was not practical using the CSPL data. Consequently, the relationship between the aggregate predictors and local membership was examined using OLS regression. The stepwise method was used, which helped alleviate any problems of multi-collinearity that can occur when there are a number of variables measuring similar phenomena.

In addition to all of the variables analysed in Table 5, a dummy variable detailing region was also included. Table 6 illustrates that party membership varies by region (or nation in the case of Scotland and Wales). This in itself might not be a significant predictor of constituency party membership. In theoretical terms, for example, there is 
little reason to suspect that those Liberal Democrat parties would tend to be more populous in East Anglia than those in the West Midlands, simply on account of the geography. However, there could potentially be an impact associated with regions that are areas of core support for the parties. Thus, if party membership in East Anglia were higher generally, there would be the potential for a 'neighbourhood' effect in the constituencies located there. In order to control for this situation, regions were divided into 'Core' or Non-Core' areas. The criterion was simply that regions with above average memberships were defined as 'core', and those with below average memberships, 'non-core'. Details of core and non-core areas are shown in Table 6. 
TABLE 6

CORE PARTY MEMBERSHIP AREAS

\begin{tabular}{|c|c|c|c|c|c|c|}
\hline & \multicolumn{2}{|c|}{ Conservative } & \multicolumn{2}{|c|}{ Labour } & \multicolumn{2}{|c|}{$\begin{array}{c}\text { Liberal } \\
\text { Democrat }\end{array}$} \\
\hline & Mean & Core & Mean & Core & Mean & Core \\
\hline South East & 1299 & $\mathrm{Y}$ & 524 & $\mathrm{~N}$ & 254 & $\mathrm{Y}$ \\
\hline East Anglia & 963 & $\mathrm{Y}$ & 628 & $\mathrm{Y}$ & 198 & $\mathrm{Y}$ \\
\hline Greater London & 774 & $\mathrm{Y}$ & 930 & $\mathrm{Y}$ & 164 & $\mathrm{Y}$ \\
\hline South West & 1296 & $\mathrm{Y}$ & 513 & $\mathrm{~N}$ & 376 & $\mathrm{Y}$ \\
\hline West Midlands & 511 & $\mathrm{~N}$ & 495 & $\mathrm{~N}$ & 118 & $\mathrm{~N}$ \\
\hline East Midlands & 666 & $\mathrm{~N}$ & 601 & $\mathrm{Y}$ & 85 & $\mathrm{~N}$ \\
\hline Yorkshire \& Humberside & 381 & $\mathrm{~N}$ & 612 & $\mathrm{Y}$ & 99 & $\mathrm{~N}$ \\
\hline North West & 388 & $\mathrm{~N}$ & 625 & $\mathrm{Y}$ & 101 & $\mathrm{~N}$ \\
\hline North & 341 & $\mathrm{~N}$ & 662 & $\mathrm{Y}$ & 103 & $\mathrm{~N}$ \\
\hline Wales & 425 & $\mathrm{~N}$ & 582 & $\mathrm{~N}$ & 104 & $\mathrm{~N}$ \\
\hline Scotland & 488 & $\mathrm{~N}$ & 385 & $\mathrm{~N}$ & 101 & $\mathrm{~N}$ \\
\hline GB Mean & 729 & & 591 & & 162 & \\
\hline
\end{tabular}


Membership of all parties is examined in Table 7. In terms of political variables, the Index of Hope and Marginality from 1992 have a positive and significant effect on local Conservative memberships. Again, Conservative parties are strongest where they are already electorally strong. Labour parties too, are more populous where they are electorally strong but unlike the Conservatives, also where the seats were more marginal following the 1992 election. Finally, it is political variables that best explain variations in Liberal Democrat membership. Liberal Democrat parties are most populous where they are already electorally successful and where the seats the more marginal following the 1992 general election. Indeed, marginality alone explained 30 per cent of the variation at the first stage of this regression. Its strong explanatory power, relative to the other variables, is well illustrated by the beta weights. 
TABLE 7

OLS REGRESSION ANALYSIS OF PARTY MEMBERSHIP 1997

\begin{tabular}{|c|c|c|c|c|c|c|c|c|c|c|c|c|}
\hline & & & servativ & & & & Labour & & & Liber & al Demo & \\
\hline & $b$ & beta & $t$ & sig & $b$ & beta & $t$ & sig & $b$ & beta & $t$ & sig \\
\hline Constant & -1389.108 & & -1.358 & & -218.230 & & -1.614 & * & 136.687 & & 1.203 & \\
\hline Index of Hope & 48.810 & .211 & 3.629 & $* * *$ & 17.604 & .251 & 3.225 & $* * *$ & 25.827 & 215 & 2.555 & $* * *$ \\
\hline Marginality 1992 & 11.696 & .199 & 4.749 & $* * *$ & -3.795 & -.180 & -3.498 & $* * *$ & -9.205 & -.542 & -6.138 & $* * *$ \\
\hline Change in Marginality $1979-1992$ & - & 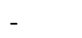 & - & - & 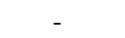 & - & - & - & - & - & - & - \\
\hline Boundary Change Index & -2.231 & -.085 & -2.180 & ** & -1.566 & -.149 & -2.947 & $* * *$ & - & - & - & 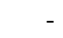 \\
\hline Number of Local Authorities & - & - & - & - & - & - & - & - & - & - & - & \\
\hline$\%$ Under $25 \mathrm{~s}$ & -126.847 & -.171 & -3.644 & $* * *$ & - & 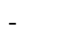 & - & - & - & - & - & \\
\hline$\%$ Households with car & - & - & - & - & - & - & - & - & - & - & - & - \\
\hline$\%$ Cou & - & - & - & - & 6.499 & .216 & 3.398 & $* * *$ & - & - & - & \\
\hline$\%$ Owner & - & - & - & - & - & . & - & - & - & - & - & \\
\hline$\%$ Private Renters & 31.344 & .155 & 2.974 & $* * *$ & 14.624 & .218 & 3.428 & $* * *$ & - & - & - & 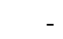 \\
\hline ally Active & - & - & - & - & - & . & - & - & - & - & - & \\
\hline$\% \mathrm{Ma}$ & 23.909 & .298 & 2.097 & ** & - & - & - & - & - & - & - & \\
\hline$\% \mathrm{Nc}$ & - & - & - & - & 11.965 & .400 & 5.391 & $* * *$ & - & - & - & \\
\hline$\&$ Managerial & 39.312 & .482 & 3.591 & $* * *$ & - & - & - & - & 6.116 & .269 & 3.420 & $* * *$ \\
\hline$\%$ in $A$ & 62.692 & .169 & 3.599 & $* * *$ & - & - & - & - & - & - & - & - \\
\hline ctare & - & - & - & - & - & - & - & - & - & - & - & \\
\hline$\% \mathrm{Wh}$ & - & - & - & - & - & - & - & - & - & - & - & . \\
\hline$\% \mathrm{~N}$ & - & - & - & - & 4.345 & .140 & 2.273 & $* *$ & - & - & - & \\
\hline Core Area & 369.698 & .235 & 5.071 & $* * *$ & - & - & - & - & - & - & - & \\
\hline Adjusted $\mathrm{r}^{2}$ & & & 17 & & & & 362 & & & & 392 & \\
\hline
\end{tabular}

Adjusted $\mathrm{r}^{2}$

Notes: $* * *=\mathrm{p}<0.01 ; * *=\mathrm{p}<0.05 ; *=\mathrm{p}<0.1 ;-=$ not significant. 
In terms of structural variables, the Boundary Change Index has a significant and negative effect on both Conservative and Labour parties. As hypothesized, increased boundary disruption appears to be to the detriment of party membership. It is worth noting, however, that boundary disruption had no statistically significant effect in the bivariate analyses of Conservative membership and thus it appears as though this variable is only influential when it interacts with the other variables in the regression. By way of contrast, structural variables have no significant impact upon Liberal Democrat membership.

For social variables, higher proportions of professional and managerial staff, private renters, agricultural employees and lower proportions of young people have a significant effect on Conservative membership, findings that are consistent with the patterns observed in the bivariate analyses. However, in the multivariate analysis the proportion of manual workers is positively signed, a finding that is counter-intuitive and one that runs counter to the initial findings in the bivariate analysis. Finally, the influence of core geographical areas is confirmed, though the Conservatives are the only party for which this variable has a significant impact. Overall social variables have a stronger impact on Conservative party memberships than political and structural ones.

For Labour, renting property from either the local authority or the private sector has a positive impact on local membership, and local parties also have higher memberships in areas where there is a higher proportion of non-whites. What is also significant however, is that the proportion of non-manual workers in a constituency is positively associated with Labour membership. This variable was not statistically significant in the bivariate analysis and thus it is only significant when it interacts with the other variables. The finding might appear to be somewhat counter-intuitive. However, there are at least two possible 
explanations. First, at the individual level Seyd and Whiteley (1992: 33) found that the membership was far more middle-class (measured by occupation) than working-class. Second, studies of participation generally have frequently pointed to greater involvement by the middle classes. Whilst one cannot infer such patterns from these aggregate data, it may be a middle-class neighbourhood effect that produces this finding. On the other hand, given the similar counter-intuitive findings on Conservative memberships, it may be that the manual/non-manual measurement has outlived its usefulness for such analyses. Ironically, the proportion of non-manual workers in the constituency has the most explanatory power of all the independent variables. However, unlike the Conservatives, the Index of Hope has a stronger impact than all other social variables.

For the Liberal Democrats, only one social variable - the proportion of professional and managerial workers in a constituency - has a significant and positive effect. Thus it would appear that aggregate patterns in the membership of the Liberal Democrats are unlike those of the other parties. There is little social basis beyond the professional and managerial class and membership levels are very much rooted in the opportunities for electoral success.

\section{Conclusion}

These analyses highlight a number of important patterns. First, Conservative constituency parties appear to be in some decline, though they are still generally far better financed than Labour or Liberal Democrat parties. Second, there are very large variations in the size of parties. Despite the large size of some, there are others with tiny memberships, some as low as six. This presents a real problem of credibility in such constituencies. Third, the wide variations in income lead to equally wide variations in expenditure. Whilst election spending 
is restricted at local level, routine expenditure is not, which theoretically may lead to cumulative distortions over time should the wide disparities continue. Fourth, individuals are very important to the finances of all parties; not only in terms of simple membership, but also in terms of the money they provide for the parties.

Thus, it is clear that discussions of the disparities in parties' wealth need to go beyond a simple focus on the national party. Since local parties do matter these wide disparities are of importance. Thus, the Conservatives may be in decline, but there is still some way to go before there is financial parity with the other main parties.

In addition, the likely impact of Committee on Standards in Public Life's (and now the government's) recommendations is of significance. The proposed increase in regulation will mean that local parties will be required to spend some effort in regulating their financial affairs. The evidence from this survey is that some constituency parties will be much better equipped than others. It was patently clear from the returns that such things as consistency or institutional memory with local parties is a key variable. Therefore, it will be a matter of some concern as to whether these additional regulations can be carried out successfully. Of course, one might argue that local parties adapted to the 1883 regulations that continue to govern election spending today (the Corrupt and Illegal Practices Act), but these only apply at elections. More stringent regulation will be required on a more regular basis. The question then arises of whether we should expect more from local parties. If parties cannot organize themselves sufficiently well or be in some way representative by way of having an acceptable level of membership, then questions about the legitimacy of party candidates must surely arise. 
The final point is that parties tend to be organizationally strong where they are already electorally strong. This is significant because since we know that local party campaigning matters, under existing electoral arrangements, this might be more likely to benefit incumbents over time. Of course, electoral change occurs, but the kind of local campaigns that are successful will have more difficulty in being mounted where the existing infrastructure is weak.

\section{ACKNOWLEDGEMENTS}

Earlier versions of this article were presented at the annual conference of the Political Studies Association, University of Nottingham, 1999 and at the annual conference of the American Political Science Association, Atlanta, 1999. I am grateful to the British Academy, London Guildhall University and the Committee on Standards in Public Life for supporting the research reported here. I am also grateful to David Denver, Charles Pattie, Colin Rallings and Michael Thrasher for their technical advice in the preparation of this article, and to Pippa Norris for supplying much of the census material. Finally, Philip Cowley's keen editorial style improved the article considerably. 


\title{
APPENDIX
}

\section{Calculation of Political and Structural Indices for Local Constituency Parties}

\author{
Index of Hope $\left(1^{\text {st }}\right.$ or $2^{\text {nd }}$ Placed Parties $)$ \\ 1992 \\ $1^{\text {st }} \quad(1987=4)(1983=3)(1979=2)$ \\ $2^{\text {nd }} \quad(1987=2)(1983=1)(1979=0.5)$ \\ $1993-1997 \quad 1^{\text {st }} \quad(1992=5)(1987=4)(1983=3)(1979=2)$ \\ $2^{\text {nd }} \quad(1992=3)(1987=2)(1983=1)(1979=0.5)$
}

Change in Marginality ( $1^{\text {st }}$ and $2^{\text {nd }}$ Placed Parties Only)

1993-97 $\quad \Sigma(m a j 92 / m a j 87-1)(m a j 87 / m a j 83-1)(m a j 83 / m a j 79-1)$

$1992 \quad \Sigma($ maj87/maj83-1) (maj83/maj79-1)

Boundary Change Index

1995-97

1997 Index of Change

Number of Local Authorities

1995-1997 Number of Local Authorities with wards in constituency

\section{NOTES}

1. The data were collected by David Denver and Gordon Hands. They surveyed Election Agents at the time of the 1997 general election and asked the following question: Roughly how many people are members of your constituency party/association? I am very grateful to David Denver and Gordon Hands for providing me with these data.

2. The correlations between constituency party membership and income for 1995 are typical for the whole period. Whilst the strength of relationship for the Conservatives and for Labour varied slightly, both were always substantially weaker than the relationship for the Liberal Democrats. 
3. Levels of party income were correlated with all aggregate variables in this article in each year for all parties. Details of the correlations are not reported in detail here. Full tables are, however, available from the author on request.

4. Levels of party expenditure were correlated with all aggregate variables in this article in each year for all parties. Details of the correlations are not reported in detail here. Full tables are, however, available from the author on request.

\section{REFERENCES}

BBC/ITN (1983) The BBC/ITN Guide to the New Parliamentary Constituencies, Chichester:

Parliamentary Research Services.

Craig, F. W. S. (ed) (1989) Britain Votes 4, Aldershot: Gower.

Denver, David (1997) 'The Results: How Britain Voted' in A. Geddes and J. Tonge (eds) Labour's Landslide, Manchester: Manchester University Press.

Denver, David and Gordon Hands (1997) Modern Constituency Electioneering, London: Frank Cass. Denver, David and Gordon Hands (1998) 'Constituency Campaigning in the 1997 General Election: Party Effort and Electoral Effort' in I. Crewe, B. Gosschalk and J. Bartle (eds) Political Communications: Why Labour Won the General Election of 1997, London: Frank Cass.

Fisher, Justin (1998) Final Report of the Local Party Income and Expenditure Survey (Published in Committee on Standards in Public Life, The Funding of Political Parties in the United Kingdom, Volume 2 Cm 4057-2, London: TSO).

Fisher, Justin (1999) 'Party Expenditure And Electoral Prospects: A National Level Analysis Of Britain', Electoral Studies 18: 519-32.

Johnston, Ron and Charles Pattie (1995) 'The Impact of Spending on Party Constituency Campaigns at Recent British General Elections', Party Politics 1: 261-75.

Rallings, Colin and Michael Thrasher (eds) (1995) Media Guide to the New Parliamentary Constituencies, Plymouth: Local Government Chronicle Elections Centre.

Seyd, Patrick and Paul Whiteley (1992) Labour's Grass Roots, Oxford: Clarendon Press. 
Seyd, Patrick (1998) 'Tony Blair and New Labour' in A. King et al. New Labour Triumphs: Britain at the Polls, Chatham, NJ: Chatham House.

Whiteley, Paul, Patrick Seyd and J. J. Richardson (1994) True Blues, Oxford: Clarendon Press. 